\title{
Pengaruh Trust Terhadap Keputusan Beli Produk Tiff Body
}

\author{
Yohana Nadya Gunardja \\ Institut Komunikasi dan Bisnis London School of Public Relations Jakarta \\ Program Studi Public Relations - Fakultas Ilmu Komunikasi \\ Email: nadyagunardja@gmail.com
}

\begin{tabular}{ll}
\hline ARTICLE INFO & ABSTRACT \\
\hline & $\begin{array}{l}\text { The shift of the Indonesian lifestyle has become online oriented has a huge impact } \\
\text { on e-commerce business's popularity. This study aims to determine the influence of } \\
\text { trust on to purchase decision of Tiff Body's product. This research uses the }\end{array}$ \\
Keywords: & quantitative methodology and data collection method to use an online \\
Trust & questionnaire with a purposive sampling technique distributed to 100 respondents \\
Purchase Decision & Linear he been shopping at Tiff Body. After the data is analyzed using Simple \\
Instagram Story & influences purchase decisions. \\
Online Shop &
\end{tabular}

\section{PENDAHULUAN}

Teknik promosi dengan menggunakan testimonial dari konsumen kini kian digemari, terutama banyak ditemukan di dalam media sosial. Hal ini menjadi menarik ditengah ramainya situasi bisnis dunia online yang tak luput dari kejahatan penipuan.

Industri kosmetik terus mengalami perkembangan dari zaman dahulu hingga saat ini. Kosmetik seperti menjadi hal yang wajib dimiliki, terutama bagi kaum wanita untuk menunjang penampilan agar selalu tampil cantik dan menarik. Dalam Surat Keputusan Badan Pengawas Obat dan Makanan (BPOM) tahun 2003 Bab 1 Pasal 1 mengatakan bahwa kosmetik adalah bahan atau sediaan untuk digunakan pada bagian luar tubuh manusia (epidermis, rambut, kuku, bibir dan organ genital bagian luar) atau gigi dan mukosa mulut, terutama untuk membersihkan, mewangikan, mengubah penampilan serta memperbaiki bau badan atau memelihara tubuh untuk tetap selalu pada kondisi baik. Hal ini menunjukkan bahwa suatu produk dapat dikategorikan sebagai kosmetik jika memenuhi kriteria tersebut. Tranggono, Iswari dan Latifah [25] mengatakan bahwa dilihat dari penggunaanya bagi kulit, kosmetik dapat digolongkan menjadi dua jenis yaitu: pertama, kosmetik perawatan kulit (skincare cosmetic), yang adalah kosmetika untuk memelihara, merawat dan mempertahankan kondisi kulit. Kedua, kosmetik riasan (dekoratif atau makeup), merupakan kosmetika untuk memperindah wajah.

Kosmetik perawatan kulit atau yang lebih dikenal sebagai skincare memiliki tujuan untuk membersihkan, merawat maupun memelihara keadaan kulit manusia, khususnya pada bagian wajah. Produk-produk yang tergolong dalam skincare antara lain sabun cuci muka, cairan pembersih muka, pelembab muka, masker dan produk-produk perawatan lainnya.

Data Kementerian Perindustrian tahun 2016 [1] mengatakan bahwa pertumbuhan pasar industri kecantikan di Indonesia rata-rata mencapai 9,67\% per tahun dalam enam tahun terakhir dari tahun 2009 hingga 2015. Pertumbuhan industri kecantikan tidak hanya mendorong merek mancanegara untuk berkembang, namun juga membuka kesempatan kepada para produsen lokal untuk semakin berkreasi dan berinovasi dalam menghasilkan skincare alami berbahan dasar tumbuhan herbal yang banyak ditemukan di Indonesia. Tiff Body merupakan salah satu produsen skincare lokal yang telah berhasil mencuri perhatian para pemburu skincare.

Tiff Body yang awalnya hanya menjual perawatan kulit untuk wajah sekarang sudah berkembang menyediakan skincare untuk bibir, tubuh, dan juga obat jerawat. Dalam kurun waktu tiga tahun, Tiff Body telah sukses menjual produknya dipasaran dan namanya sudah dikenal luas di media sosial dengan followers Instagram sebanyak 149.000 pengikut. 
Media sosial juga turut berperan dalam perkembangan industri kecantikan, khususnya di Indonesia. Media sosial yang awalnya diciptakan untuk menjalin pertemanan melalui internet, berujung menjadi wadah untuk beriklan secara gratis bagi para pengusaha muda yang belum memiliki dana besar untuk beriklan. Media sosial dianggap lebih efisien dibandingkan memasang iklan melalui media lain [21].

Berdasarkan data dari Asosiasi Penyelenggara Jasa Internet Indonesia (APJII) [3], sebesar $55,39 \%$ dari total 2.500 responden di Indonesia mengakses internet lebih dari enam jam dalam satu hari. Sementara sisa responden lainnya, mulai dari dua sampai enam jam dalam satu hari. Selain itu, diketahui sejumlah 76,67\% responden mengakses internet hingga tiga kali atau lebih dalam setiap jam, sedangkan sisa responden lainnya melakukan hal tersebut sekali dalam satu sampai beberapa jam. Data statistik APJII juga menunjukkan bahwa sebanyak $89.35 \%$ masyarakat menggunakan internet untuk chatting, disusul dengan mengakses media sosial sebanyak $87.13 \%$. Media sosial yang dimaksud adalah Facebook, Instagram dan Twitter.

Instagram adalah platform yang didesain untuk berbagi foto dan video berdurasi singkat. Instagram tersusun dari dua buah kata yaitu "insta" dan "gram". Insta diambil dari kata instan, yang memiliki arti mudah dalam mengakses dan melihat gambar melalui foto yang di unggah melalui media sosial. Gram yang adalah singkatan dari telegram, memiliki arti mengirim sesuatu (foto) kepada pihak lain [9]. Instagram memiliki pengguna aktif bulanan yang telah menembus satu miliar pengguna per Juni 2018 [4]. Namun keunggulan ini dimanfaatkan untuk menjadi media promosi produk selayaknya buku katalog, sehingga orang-orang dapat dengan mudah melihat produk apa saja yang dijual oleh perusahaan tersebut dan tertera informasi yang mendukung mengenai produk yang dijual.

Seperti pada umumnya, Tiff Body juga mengimplementasikan hal tersebut ke dalam akun Instagram mereka dengan username @Tiff_body. Tiff Body seringkali mengunggah foto dan video untuk menjelaskan kegunaan dari produknya, bagaimana cara menggunakan, berbagi tips and trick, dan menampilkan testimonial dari para pelanggan yang sudah pernah membeli dan menyukai produknya.

Namun dengan menjamurnya pertumbuhan online shop baru yang tidak sedikit melakukan kasus penipuan. Berdasarkan data dari Kementerian Komunikasi dan Informatika Republik Indonesia (KEMKOMINFO) pada tahun 2018, sebanyak 14.000 dari 16.678 kasus laporan yang diterima situs tersebut merupakan tindak kejahatan penipuan transaksi online [2]. Pramudito [19] juga mengatakan bahwa telah beredar kosmetik palsu yang dijual secara online. Harga miring dan pengetahuan masyarakat yang minim menjadi alasan kosmetik palsu laku di pasaran. Hal ini menjadi masalah yang perlu ditangani secara serius karena make up palsu memiliki akibat buruk bagi kesehatan. Menurut Nuari [18], make up palsu mungkin tidak disadari perbedaannya ketika digunakan secara langsung, namun dampaknya akan terlihat dalam jangka panjang. Hal yang mengkhawatirkan adalah jika produk tersebut menggunakan merkuri, timah, cyanide, dan sederet bahan-bahan bahaya lainnya untuk menjadi bahan pembuatan make up dengan takaran yang berlebihan karena dapat berakibat luka bakar, menimbulkan bercak pada wajah, iritasi mata, dan alergi kulit.

Berdasarkan penelitian sebelumnya yang dilakukan oleh Wang [27], dikemukakan bahwa kepercayaan konsumen terhadap merek memiliki pengaruh yang besar dalam sikap konsumen dalam mengevaluasi toko dan niat pembelian. Hal in menjadi menarik ketika Pratama bersama Suharyono dan Pratama [20] menemukan bahwa variabel yang berpengaruh secara signifikan terhadap keputusan pembelian adalah variabel international brand image dan kualitas produk. Berdasarkan latar belakang diatas, maka tujuan penelitian ini adalah untuk mengetahui pengaruh trust terhadap keputusan beli produk Tiff Body.

\section{KERANGKA TEORITIS}

\section{Trust}

Chaudhuri dan Holbrook [5], menjelaskan kepercayaan merek dapat diartikan sebagai kemauan konsumen rata-rata untuk mengandalkan kemampuan merek untuk melakukan fungsi yang dinyatakannya. Menurut Ha dan Perks [10], trust adalah tolak ukur pelanggan untuk mengandalkan kemampuan merek untuk menjalankan fungsi yang diperankannya. Sedangkan Resnick dan Montania [22] menyatakan kepercayaan merek adalah keyakinan atau harapan bahwa perkataan penjual dapat diandalkan dan penjual tidak akan mengambil keuntungan dari kelemahan pelanggan. Merujuk pernyataan dari beberapa ahli, trust dapat didefinisikan sebagai keyakinan, harapan dan kemauan 
konsumen untuk mengandalkan kemampuan penjual atau merek sesuai dengan fungsinya dan tidak mengambil keuntungan dari kelemahan pelanggan.

Menurut Lau dan Lee [16] terdapat tiga faktor yang dapat mempengaruhi kepercayaan terhadap sebuah merek, yaitu pertama, Brand characterictic merupakan hal yang penting sebelum seseorang membuat keputusan dalam mempercayai sebuah merek, karena calon konsumen akan melakukan perbandingan terhadap beberapa merek yang sejenis sebelum melakukan transaksi. Brand characteristic yang dapat mempengaruhi trust adalah brand reputation, brand predictability, dan brand competence. Brand reputation menentukan apakah merek tersebut dapat dipercaya atau tidak. Jika sebuah merek memiliki reputasi yang baik berdasarkan pendapat para konsumen, maka hal ini mampu menguatkan kepercayaan terhadap merek tersebut. Brand predictability adalah harapan konsumen dalam mendapatkan kepercayaan dari merek yang disebabkan dari pengalaman konsumen sebelumnya yang merasa merek tersebut mampu memenuhi harapannya. Brand predictability muncul karena tingkat konsistensi yang kuat dari merek tersebut. Brand predictability juga bisa dikatakan sebagai pengenalan dimana satu pihak mempelajari lebih dalam tentang pihak lain. Brand competence adalah kemampuan sebuah merek untuk menyelesaikan masalah-masalah yang dihadapi konsumen dan mampu memenuhi kebutuhan konsumen.

Kedua, company characterictic merupakan hal yang mendukung dalam meningkatkan kepercayaan konsumen terhadap sebuah merek. Pengetahuan konsumen tentang perusahaan dijadikan dasar awal untuk memiliki kepercayaan kepada merek tersebut.

Ketiga, consumer-brand characterictic adalah keterkaitan antara konsumen dengan merek. Karakteristik konsumen dapat mempengaruhi kepercayaan terhadap sebuah merek. Karakteristik yang disebutkan berupa similaritas antara konsep diri konsumen dengan brand personality, brand liking, dan brand experience.

Kepercayaan yang didapatkan konsumen dari perusahaan akan menjadi keunggulan tersendiri bagi perusahaan tersebut. Di dalam bisnis online shopping, tingkat kepercayaan konsumen sangat dibutuhkan karena di dunia online, konsumen tidak terlibat secara langsung atau bertatap muka dengan pihak perusahaan namun hanya melakukan komunikasi jarak jauh. Disamping itu, produk yang ditawarkan perusahaan hanya dalam bentuk foto yang ditampilkan melalui web site online shopping. Perusahaan sebagai penjual harus mampu memberikan rasa aman kepada konsumen.

Menurut Kapferer [12], kepercayaan penting bagi konsumen karena kepercayaan akan membantu mengefisienkan waktu, mengurangi risiko konsumen terhadap merek, meniminalisir pemilihan merek dan mengurangi waktu yang diperlukan untuk memutuskan pembelian. Tingkat kepercayaan konsumen sangat dibutuhkan dalam bisnis online shopping karena perusahaan harus mampu memberikan rasa aman kepada konsumen.

Kepercayaan merek merefleksikan dua hal yakni brand reliability dan brand intentions [6]. Brand reliability atau kehandalan merek yang bersumber pada keyakinan konsumen bahwa produk tersebut mampu memenuhi nilai yang dijanjikan atau dengan kata lain, merek tersebut mampu memenuhi kebutuhan dan memberikan kepuasan kepada konsumen. Brand reliability merupakan hal yang penting bagi terciptanya kepercayaan terhadap merek karena kemampuan merek memenuhi nilai yang dijanjikannya akan membuat konsumen menaruh rasa yakin akan mendapatkan apa yang dibutuhkan, dalam hal ini kebutuhan untuk keluar dari perasaan terancamnya.

Brand intention didasarkan pada keyakinan konsumen bahwa merek tersebut mampu mengutamakan kepentingan konsumen ketika mengalami masalah dengan produk yang muncul secara tidak terduga. Brand intention juga mendeskripsikan aspek kepercayaan melalui bukti yang ada untuk membuat orang-orang merasa terjamin, bahwa merek akan bertanggung jawab dan peduli meskipun ada permasalahan dengan produk di waktu yang akan datang.

\section{Keputusan Beli}

Menurut Kotler dan Armstrong [13], keputusan pembelian konsumen adalah membeli merek yang paling disukai dari berbagai alternatif yang ada, tetapi dua faktor bisa berada antara niat pembelian dan keputusan pembelian. Faktor pertama adalah sikap orang lain dan faktor yang kedua adalah faktor situasional. Definisi lain dari keputusan pembelian adalah keputusan konsumen mengenai preferensi atas merek-merek yang ada didalam kumpulan pilihan [14]. Selain itu, Marlius [17] juga mengemukakan bahwa keputusan pembelian adalah suatu keputusan karena ketertarikan yang dirasakan oleh seseorang terhadap suatu produk, dan ingin membeli, mencoba, menggunakan, atau memiliki produk tersebut. Maka dari itu, peneliti menyimpulkan keputusan beli berdasarkan 
pengertian dari beberapa ahli adalah keputusan konsumen untuk membeli produk yang paling disukai dari berbagai pilihan produk-produk lainnya yang sejenis.

Menurut Kotler, et al. [14] perilaku pembelian konsumen dipengaruhi oleh tiga faktor, yaitu faktor budaya, faktor sosial, dan faktor pribadi. Faktor budaya, sub-budaya, dan kelas sosial merupakan hal yang penting dalam perilaku pembelian karena budaya merupakan penentu keinginan dan perilaku yang paling dasar dari sifat manusia. Faktor sosial juga memiliki peranan yang penting dalam perilaku keputusan pembelian, diantaranya kelompok acuan, keluarga, peran dan status. Keputusan pembelian juga dapat dipengaruhi oleh karakteristik pribadi, diantaranya usia dan tahap siklus hidup, pekerjaan, keadaan ekonomi, gaya hidup, serta kepribadian dan konsep diri pembeli.

Menurut Kotler dan Armstrong [13] terdapat lima tahapan dalam keputusan pembelian, yaitu pertama, pengenalan kebutuhan (need recognition). Proses pembelian diawali dengan adanya pengenalan atau kesadaran akan kebutuhan. Kebutuhan dapat dipicu melalui rangsangan internal ketika kebutuhan normal terjadi pada tingkat yang cukup tinggi hingga menimbulkan dorongan, seperti misalnya lapar dan haus. Kebutuhan juga bisa dipicu oleh rangsangan eksternal, seperti misalnya berdiskusi dengan teman dapat menimbulkan kebutuhan baru yang sebelumnya tidak terfikirkan, contohnya untuk membeli mobil baru. Konsumen dalam tahap ini perlu diyakinkan mengenai kebutuhan, masalah apa yang timbul, apa yang menyebabkan, dan bagaimana masalah itu dapat mengarahkan konsumen pada produk tertentu sehingga ia akan melakukan langkah berikutnya untuk mencari informasi. Iklan memiliki peran besar untuk mempengaruhi konsumen pada tahap ini.

Kedua, pencarian informasi (information search). Di tahap ini konsumen mulai mencari informasi sebanyak-banyaknya mengenai produk yang dibutuhkan. Semakin banyak informasi yang diperoleh, kesadaran konsumen dan pengetahuan akan merek dan fitur yang tersedia juga meningkat. Informasi juga membantu untuk mengevaluasi merek setelah melalui pertimbangan. Informasi bisa didapatkan dari beberapa sumber, yang meliputi sumber pribadi yaitu keluarga, teman, tetangga, dan rekan. Selanjutnya ada sumber komersial, yaitu iklan, situs web, kemasan, tampilan, dan lain lain. Lalu sumber publik, yaitu media massa, pecarian internet, dan organisasi pemeringkat konsumen. Yang terakhir yaitu sumber pengalaman yang meliputi penanganan, pemeriksaan, dan pemakaian produk. Sumber informasi yang paling efektif adalah sumber pribadi untuk melegitimasi dan melakukan evaluasi produk, namun sumber komersial membantu untuk menyediakan informasi.

Ketiga, evaluasi alternatif (evaluation of alternatives). Evaluasi alternative adalah tahap dimana konsumen sudah memiliki beberapa alternatif barang atau merek dan mulai menimbangnimbang. Faktor yang mempengaruhi konsumen dalam melakukan evaluasi merek adalah pribadi konsumen tersebut, situasi pembelian, dorongan dari diri maupun sekitar, atau bahkan tidak melakukan evaluasi sama sekali. Konsumen biasanya memiliki kriteria yang mempengaruhi keputusan pembeliannya. Pemasar harus mempelajari pembeli untuk menemukan bagaimana cara konsumen untuk mengevaluasi merek dan mempengaruhi keputusan beli.

Keempat, keputusan pembelian (purchase decision). Ini adalah tahapan dimana konsumen sudah mengevaluasi pilihan yang ada dan membentuk niat pembelian. Pada umumnya, keputusan pembelian konsumen jatuh kepada merek yang paling disukai, tetapi terdapat dua faktor yang berada diantara niat pembelian dan keputusan pembelian. Faktor pertama adalah sikap orang lain yang dekat dengan konsumen akan lebih mempengaruhi keputusan pembelian konsumen. Faktor kedua adalah faktor situasional yang tidak diharapkan, yaitu keadaan yang tidak terduga dapat mengubah niat pembelian.

Kelima, perilaku pasca-pembelian (post purchase behavior). Tahap ini merupakan tahapan setelah melakukan pembelian dimana pemasar harus tetap memperhatikan kepuasan konsumen. Konsumen yang puas adalah konsumen yang ekspektasinya terpenuhi dan mampu meningkatkan kemungkinan untuk belanja ulang. Namun jika mengecewakan akan menimbulkan keraguan untuk berbelanja ulang. Semakin besar kesenjangan antara ekspektasi dan kinerja, semakin besar pula ketidakpuasan konsumen. Hal ini menunjukkan bahwa pemasar disarankan untuk menjanjikan apa yang dapat dipenuhinya sehingga konsumen dapat terpuaskan.

\section{Teori S-O-R}

Pendekatan teori yang digunakan dalam penelitian ini adalah teori S-O-R atau stimulus organisme - respon yang menyatakan bahwa penyebab perubahan sikap dan perilaku sangat tergantung dari kualitas rangsangan (stimulus) ketika berkomunikasi dengan organisme tersebut. Efek yang ditimbulkan dari stimulus response ini adalah reaksi khusus terhadap stimulus khusus, sehingga 
seseorang mampu memperkirakan dan mengharapkan kesesuaian antara pesan dan reaksi komunikan [7]. Stimulus atau pesan yang disampaikan kepada komunikan bisa diterima maupun ditolak. Namun komunikasi bisa berlangsung jika ada perhatian dari komunikan. Proses berikutnya, komunikan akan memahami, jika diterima maka akan terjadi kesediaan untuk mengubah sikap.

\section{METODE PENELITIAN}

Penelitian ini menggunakan pendekatan kuantitatif. Riset kuantitatif adalah riset yang menggambarkan atau menjelaskan suatu masalah yang hasilnya dapat digeneralisasikan [15].

Dalam metode penelitian, kata populasi diartikan sebagai wilayah generalisasi yang terdiri atas objek atau subjek yang mempunyai kuantitas dan karakteristik tertentu yang ditetapkan oleh peneliti untuk dipelajari yang kemudian ditarik kesimpulannya [11]. Populasi yang digunakan dalam penelitian ini adalah konsumen Tiff Body yang juga merupakan followers Instagram @Tiff_body sebanyak 149.000 pengikut. Rata-rata customer Tiff Body berusia 17-35 tahun yang didominasi oleh wanita.

Sampel adalah sub dari seperangkat elemen yang digunakan peneliti untuk dipelajari [23]. Rumus yang digunakan untuk mengetahui jumlah sampel adalah slovin.

$$
n=\frac{\mathrm{N}}{1+\mathrm{Ne}^{2}}
$$

Keterangan:

$\mathrm{n}=$ ukuran sampel

$\mathrm{N}=$ Followers @Tiff_Body

e = Kelonggaran ketidaktelitian karena kesalahan pengambilan sampel yang dapat di tolerir $1 \%-10 \%$

$$
\begin{gathered}
n=\frac{149.000}{1+149.000(0,1)^{2}} \\
=99,932=100 \text { responden }
\end{gathered}
$$

Pada penelitian ini, peneliti menggunakan non-probability sampling, yaitu teknik memilih sampel dengan tidak memberikan kesempatan yang sama untuk menjadi responden dengan pertimbangan peneliti [11]. Teknik non-probability sampling yang digunakan adalah purposive sampling, dimana kuisioner online hanya diberikan kepada responden dengan kriteria-kriteria tertentu yang telah ditentukan sesuai dengan tujuan penelitian. Kharakteristik yang ditentukan oleh peneliti dalam penelitian ini yakni seseorang yang sudah pernah membeli dan menggunakan produk skin care Tiff Body. Peneliti menggunakan kriteria tersebut dengan keyakinan orang-orang yang sudah pernah membeli produk Tiff Body akan lebih mengetahui testimonial yang digunakan dan juga kualitas produk dari Tiff Body sehingga diharapkan hasil yang didapatkan dapat diuji kebenarannya.

Untuk mengetahui sejauh mana hubungan variabel $\mathrm{X}$ dengan variabel $\mathrm{Y}$, sehingga dari hasil penyebaran kuesioner dapat dihasilkan data yang dapat di formulasikan dengan program IBM SPSS Statictics 25, sehingga menghasilkan data-data yang berupa angka untuk dapat dianalisa dan ditarik kesimpulan.

Skala yang digunakan dalam skala pengukuran ini adalah Skala Likert. Menurut Kriyantono [15], Skala Likert digunakan untuk mengukur sikap responden mengenai suatu objek. Teknik analisis data yang dilakukan adalah dengan menggunakan persamaan regresi linear sederhana. Persamaannya adalah sebagai berikut:

$\mathrm{Y}=\mathrm{a}+\mathrm{bX}$

Keterangan:

$\mathrm{Y}=$ Subyek dalam variabel dependen yang diprediksi

$\mathrm{a}=$ Harga $\mathrm{Y}$ bila $\mathrm{X}=0$ (Harga konstanta)

$\mathrm{b}=$ Angka atau arah koefisien regresi, yang menunjukkan angka 
Koefisien determinasi dalam penelitian ini menunjukkan besar pengaruh trust (variabel X) terhadap keputusan beli produk Tiff Body. Untuk mengetahui nilai koefisien determinasi maka dapat menggunakan rumus:

$\mathrm{KD}=\mathrm{R}^{2} \times 100 \%$

$\mathrm{KD}=$ Koefisien determinasi

$\mathrm{KD}=0$, berarti pengaruh variabel $\mathrm{X}$ terhadap variabel $\mathrm{Y}$ lemah

$\mathrm{KD}=1$, berarti pengaruh variabel $\mathrm{X}$ terhadap variabel $\mathrm{Y}$ kuat

\section{HASIL PENELITIAN DAN DISKUSI}

Analisis regresi digunakan untuk memprediksi pengaruh variabel bebas terhadap variabel terikat. Dalam penelitian ini menggunakan analisis regresi linear sederhana, dimana variabel penelitian terdiri dari satu variabel dependen dan satu variabel independen.

\begin{tabular}{|c|c|c|c|c|c|}
\hline \multirow[b]{3}{*}{ Model } & \multicolumn{5}{|c|}{$\begin{array}{l}\text { Tabel 1. Hasil Output SPSS Coefficients } \\
\text { Coefficients }^{\mathrm{a}}\end{array}$} \\
\hline & Unstandardized C & oefficients & Standardized Coefficients & & \\
\hline & B & Std. Error & Beta & & Sig. \\
\hline (Constant) &, 186 & 3,738 & & 050 & 960 \\
\hline Trust & 1,393 & , 143 & ,701 &, 720 &, 000 \\
\hline
\end{tabular}

\section{Persamaan Regresi Linear Sederhana}

Berdasarkan hasil pengujian linear sederhana pada tabel 1 di atas, diperoleh besarnya pengaruh trust terhadap keputusan beli produk Tiff Body. Hasil $(\beta)=0,701$. Koefisien korelasi yang kuat berada pada jarak 0,60 - 0,799. Untuk mencari hubungan antara dua variabel atau lebih yang mempunyai hubungan fungsional atau sebab akibat digunakan rumus persamaan regresi linear, sebagai berikut :

$$
\begin{aligned}
& Y=a+b X \\
& Y=0,186+1,393 X
\end{aligned}
$$

Konstanta sebesar 0,186 memiliki arti jika trust (X) memiliki nilai sejumlah 0, maka tingkat keputusan pembelian (Y) nilainya sebesar 0.186. Koefisien regresi variabel trust $(\mathrm{X})$ sebesar 1,393, artinya jika trust mengalami peningkatan sebesar 1, maka tingkat keputusan pembelian (Y) akan mengalami peningkatan sebesar 1,393 . Koefisien bernilai positif memiliki makna bahwa trust (X) berpengaruh positif terhadap keputusan beli (Y).

\section{Uji Determinants}

\begin{tabular}{lr|r|l|l}
\multicolumn{3}{c}{ Model Summary } & \multicolumn{3}{c}{ Tabel 2. Hasil Output SPSS Model Summary } \\
\multicolumn{2}{c|}{ Model } & R Square & Adjusted R Square & Std. Error of the Estimate \\
\hline 1 &, 491 &, 486 & 4,60636 \\
\hline
\end{tabular}

Berdasarkan tabel 2 diatas diketahui nilai $\mathrm{R}$ square $=0.491$. Nilai ini memiliki arti bahwa pengaruh trust (X) terhadap keputusan beli (Y) adalah sebesar 49,1\%, sedangkan 50,9\% keputusan beli dipengaruhi oleh variabel lain yang tidak diteliti.

Berdasarkan pembahasan di atas, maka dapat disimpulkan bawa trust $(\mathrm{X})$ berpengaruh positif terhadap keputusan beli (Y) dengan total pengaruh sebesar 49,1\%. Pengaruh positif ini bermakna semakin meningkatnya trust pada seorang pelanggan maka akan berpengaruh terhadap peningkatan keputusan pelanggan tersebut. 


\section{Uji Hipotesis Dalam Analisis Regresi Linear Sederhana}

Uji hipotesis dengan menggunakan uji parsial atau uji t digunakan untuk menguji antara variabel bebas terhadap variabel terikat. Berdasarkan tabel 1 diatas, besaran uji parsial atau nilai t hitung $=9,720$ dan sig 0,000 . Ha hipotesis diterima (ada pengaruh yang positif dan signifikan dari trust terhadap keputusan beli) jika nilai sig. lebih kecil dari 0,05, maka trust berpengaruh terhadap keputusan beli. Dari hasil penelitian menunjukkan bahwa nilai sig. trust terhadap keputusan beli = 0,000 lebih kecil dari 0,05. Dengan demikian, ada pengaruh trust terhadap keputusan beli.

$$
\begin{aligned}
& \text { Df }=\mathrm{n}-\mathrm{k} \\
& =100-2=98 \\
& \text { Taraf signifikansi } 2 \text { sisi }(5 \%)=0.025 \\
& \text { Hasil }=1,98447
\end{aligned}
$$

\section{Hipotesis Penelitian dan Hipotesis Statistik}

Terdapat hubungan positif dan signifikan antara trust dengan keputusan beli produk Tiff Body.

H0 : $(\mathrm{r} x \mathrm{y}=0)$ Tidak ada pengaruh trust terhadap keputusan beli produk Tiff Body.

Ha : $(\mathrm{r} x \mathrm{y} \neq 0)$ Ada pengaruh trust terhadap keputusan beli produk Tiff Body.

Sehingga kesimpulannya adalah H0 ditolak dan Ha diterima, ada pengaruh trust terhadap keputusan beli produk Tiff Body karena terbukti thitung $>\mathrm{t}$ tabel $(9,720>1,98447)$.

\section{Diskusi}

Hasil penelitian menunjukan bahwa terdapat pengaruh antara variabel X yakni trust terhadap variabel Y keputusan beli produk Tiff Body. Hal ini dibuktikan dengan uji t pada variabel pesan kampanye terhadap perubahan sikap. Dapat diketahui bahwa sig untuk variabel pesan kampanye adalah .000 dan jika dibandingkan dengan 0,05 terlihat bahwa sig $<0,05$ yang dapat disimpulkan bahwa Ho ditolak dan Ha diterima yang artinya variabel trust berpengaruh secara signifikan terhadap keputusan beli. Perhitungan yang dilakukan dengan menggunakan program SPSS menunjukan hasil nilai pengaruh untuk X (trust) sebesar 1,393 terhadap Y (keputusan beli).

Hasil ini sejalan dengan penelitian Verina, Yulianto, dan Latief $(2014$, p.9), bahwa kepercayaan merupakan faktor penting yang mampu memengaruhi konsumen untuk membeli sebuah produk. Ketika sebuah produk dijual secara online, dimana produk dari toko tersebut tidak dapat dilihat dan toko tidak dapat ditemui secara langsung, maka kepercayaan menjadi kunci bagi konsumen untuk memutuskan akan membeli produk atau tidak. Wibowo, Sari, dan Saidani (2017, p.334) juga menyatakan bahwa ketika kepercayaan yang diberi oleh penjual dapat memenuhi harapan, maka akan tercipta keputusan pembelian.

Berdasarkan hasil penelitian, kepercayaan dari pelanggan Tiff Body terbangun dari adanya pengalaman baik yang dialami para pelanggan selama menggunakan produk Tiff Body dan mampu memenuhi ekspektasi dari para konsumen, sehingga walaupun produk Tiff Body dijual secara online dan tidak bisa dilihat secara langsung, namun para pelanggan memiliki kepercayaan bahwa produk Tiff Body dapat memenuhi harapannya. Hal ini dibuktikan dengan banyaknya testimonial dari konsumen yang sudah pernah membeli produk Tiff Body dan merasa puas.

\section{SIMPULAN}

Keputusan beli produk Tiff Body, maka dapat diperoleh kesimpulan bahwa trust berpengaruh positif dan signifikan terhadap keputusan beli karena kepercayaan merupakan faktor penting yang mampu mempengaruhi konsumen untuk membeli sebuah produk terutama secara online, dimana produk tidak dapat dijumpai secara langsung, maka kepercayaan menjadi kunci bagi konsumen untuk memutuskan akan membeli produk atau tidak.

\section{Saran}

Saran untuk Tiff Body agar dapat terus mempertahankan kualitas dan mutu produk untuk menjaga kepercayaan pelanggan yang sudah terbangun, misalnya pemeriksaan secara berkala pada bahan baku yang digunakan, pengendalian produksi yang dilakukan secara terus menerus meliputi 
pengendalian bahan baku dan proses produksi, memenuhi persyaratan dalam pengemasan produk, dan melakukan pemeriksaan dan pengujian selama proses dan produk akhir untuk mengetahui kualitas produk dan dihasilkan untuk memenuhi persyaratan prosedur yang telah ditetapkan. Akan lebih baik jika kualitas secara pelayanan dapat ditingkatkan agar kepercayaan pelanggan juga semakin meningkat dan meluas, seperti contohnya membuat komitmen untuk memberikan pelayanan yang terbaik untuk pelanggan.

\section{DAFTAR PUSTAKA}

[1] Amalia, L. 2017. Tren Dan Perilaku Pasar Kosmetik Indonesia Tahun 2017. Diperoleh dari website Sigma Research (http://sigmaresearch.co.id/tag/data-penjualan-kosmetik-di-indonesia/).

[2] Arnani, M. 2018. 16.000 Laporan Diterima Cek Rekening.Id, Penipuan "Online" Capai 14.000. Diperoleh dari website Kompas (https://nasional.kompas.com/read/2018/09/11/15014481/16000-laporan-diterimacekrekeningid-penipuan-online-capai-14000. Diakses).

[3] Asosiasi Penyelenggara Jasa Internet Indonesia (APJII). (2017). Penetrasi \& Perilaku Pengguna Internet Indonesia. Diperoleh dari website APJII (https://apjii.or.id/survei2017/kirimlink).

[4] Bohang, F. K. 2018. Pengguna Aktif Instagram Tembus 1 Miliar. Diperoleh dari website Tekno Kompas (https://tekno.kompas.com/read/2018/06/21/10280037/juni-2018-pengguna-aktifinstagram-tembus-1-miliar).

[5] Chaudhuri, A. \& Holbrook, M. B., 2001. The Chain of Effects from Brand Trust and Brand Affect to Brand Performance: The Role of Brand Loyalty. Journal of Marketing, Vol. 65, (hal:81-93).

[6] Delgado-Ballester, E., Munuera-Aleman, J. L. \& Yague-Guillen, M. J., 2003. Development and Validation of a Brand Trust Scale. Journal of Market Research, Vol. 45, No. 1, (hal:35-53).

[7] Effendy, O. U. 2003. Ilmu, Teori, dan Filsafat Komunikasi. Bandung: PT Citra Aditya Bakti.

[9] Ghazali, M. 2016. Buat Duit dengan Facebook dan Instagram: Panduan Menjana Pendapatan dengan Facebook dan Instagram. Malaysia: Publishing House.

[10] Ha, H. \& Perks, H. 2015. Effects of consumer perceptions of brand experience on the web: brand familiarity, satisfaction, and brand trust. Journal of Consumer Behaviour, Vol. 4, No. 6, (hal:438-452).

[11] Hikmat, M. M. 2017. Metode Penelitian Dalam Perspektif Ilmu Komunikasi Dan Sastra. Jakarta: Graha Ilmu.

[12] Kapferer, J. N., 2008. New Strategic Brand Management: Creating and Sustaining Brand Equity Long Term. London and Philadelphia: Kogan Page Limited.

[13] Kotler, P. \& Armstrong, G. 2008. Prinsip-Prinsip Pemasaran. Edisi 12. Jilid 1. Jakarta: Erlangga.

[14] Kotler, P., Keller, K. L., Ang, S. H., Leong, S. M. \& Tan, C. T., 2009. Marketing Management, 5th Ed, an Asian Perspective. Singapore: Pearson Education, Inc.

[15] Kriyantono, R. 2010. Teknis Praktis Riset Komunikasi Disertai Contoh Praktis Riset Media. Jakarta: Kencana.

[16] Lau, G. T. \& Lee, S. H., 1999. Consumers' Trust in a Brand and The Link to Brand Loyalty. Journal of Market Focused Management, Vol. 4, (hal: 341-370). 
[17] Marlius, D. 2017. Keputusan Pembelian Berdasarkan Faktor Psikologis dan Bauran Pemasaran PT. Intercom Mobilindo Padang. Jurnal pundi, Vol. 1, No. 1, (hal:57-61).

[18] Nuari, A. 2017. Waspada Bahaya Memakai Makeup Palsu! Diperoleh dari website Cosmogirl (http://www.cosmogirl.co.id/artikel/read/9643/Waspada-Bahaya-Memakai-Makeup-Palsu).

[19] Pramudito, A. 2016. Banyak Yang 'Gila Label', Peluang Bagi Penipu Bikin Kosmetik AbalAbal. Diperoleh dari website Surabaya Tribun News (http://surabaya.tribunnews.com/2016/10/21/banyak-yang-gila-label-peluang-bagi-penipu-bikinkosmetik-abal-abal?page=all).

[20] Pratama, A. R., Suharyono \& Sunarti. 2016. Pengaruh International Brand Image dan Kualitas Produk Terhadap Keputusan Pembelian. Jurnal Administrasi Bisnis (JAB), Vol. 23, No. 1, (hal:1-7).

[21] Ramadhani, Y. 2017. Mengapa Media Sosial Jadi Sarana Menjual Produk? Diperoleh dari website Tirto.id (https://tirto.id/mengapa-media-sosial-jadi-sarana-menjual-produk-cu46).

[22] Resnick, M. L. \& Montania, R., 2010. Perceptions of Customer Service, Information Privacy, and Product Quality from Semiotic Design Features in an Online Web Store. International Journal of Human-Computer Interaction, Vol. 16, No. 2, (hal:211-234).

[23] Sarwono, J. 2006. Metode Penelitian Kuantitatif dan Kualitatif. Yogyakarta: Graha Ilmu.

[24] Surat Keputusan Badan Pengawas Obat dan Makanan (BPOM). 2003. Kosmetik. Jakarta: Badan Pengawas Obat dan Makanan Republik Indonesia.

[25] Tranggono, Iswari, R. \& Latifah, F. 2007. Buku Pegangan Ilmu Pengetahuan Kosmetik. Jakarta: Gramedia Pustaka Utama.

[26] Verina, E., Yulianto, E. \& Latief, W. A. 2014. Faktor-faktor yang Mempengaruhi Keputusan Pembelian pada Toko Fashion di Jejaring Sosial Facebook. Jurnal Administrasi Bisnis, Vol. 10, No. 1, (hal:1-10).

[27] Wang, S. A. (2003). Customer Testimonials and New Clips as Contextual Cues in the Consumer Cognitive Processing of Online Shopping. Journal of Promotion Management, Vol. 9, No. 1-2, (hal: 145-162).

[28] Wibowo, S. F., Sari, E. P. \& Saidani, B. (2017). The Effect of Trust and Brand Image on Purchase Decree (Us Toyota Car Survey in Jakarta Region). Jurnal Riset Manajemen Sains Indonesia, Vol. 8, No. 2, (hal: 317-337). 